\title{
Is Mental Practice an Effective Adjunct Therapeutic Strategy for Upper Limb Motor Restoration After Stroke? A Systematic Review and MetaAnalysis
}

Sérgio Machado; Eduardo Lattari; Alberto Souza de Sá; Nuno B.F. Rocha; Ti-Fei Yuan; Flávia Paes; Mirko Wegner; Henning Budde; Antonio E. Nardi; Oscar Arias-Carrión

\begin{abstract}
Stroke is one of the most common conditions requiring rehabilitation, and its motor impairments are a major cause of permanent disability. Hemiparesis is observed by $80 \%$ of the patients after acute stroke. Neuroimaging studies showed that real and imagined movements have similarities regarding brain activation, supplying evidence that those similarities are based on the same process. Within this context, the combination of mental practice (MP) with physical and occupational therapy appears to be a natural complement based on neurorehabilitation concepts. Our study seeks to investigate if MP for stroke rehabilitation of upper limbs is an effective adjunct therapy. PubMed (Medline), ISI knowledge (Institute for Scientific Information) and SciELO (Scientific Electronic Library) were terminated on 20 February 2015. Data were collected on variables as follows: sample size, type of supervision, configuration of mental practice, setting the physical practice (intensity, number of sets and repetitions, duration of contractions, rest interval between sets, weekly and total duration), measures of sensorimotor deficits used in the main studies and significant results. Random effects models were used that take into account the variance within and between studies. Seven articles were selected. As there was no statistically significant difference between the two groups (MP vs control), showed a -0.6 ( $95 \% \mathrm{Cl}:-1.27$ to 0.04 ), for upper limb motor restoration after stroke. The present metaanalysis concluded that MP is not effective as adjunct therapeutic strategy for upper limb motor restoration after stroke.
\end{abstract}

\section{Keywords}

Hemiparesis, mental practice, physical practice, stroke.

\section{INTRODUCTION}

Stroke is one of the most common conditions requiring rehabilitation, and its motor impairments are a major cause of permanent disability [1-3]. Studies showed that approximately $80 \%$ of patients in acute phase post stroke present some type of motor impairment, such as hemiparesis [4]. Concerning hemiparesis, one of the most common and disabling impairments [5], studies have provided evidence that rehabilitation efficacy is restricted to unsatisfactory results [6,7], with regard to $30 \%$ to $60 \%$ of stroke patients whose more affected arms remain with no functionality after discharge [8]. Hand rehabilitation is vital to allow patients to perform activities of daily living (e.g., pick up a cup), however, there is not only a higher variability related to rehabilitation techniques used, but also it seems these are not totally complete techniques [9]. In particular, techniques based on neuroscience have been gaining strength, popularity and space as a new approach of treatment to improve outcome even in situations which patients present permanent deficits [10]. Thus, the development of new rehabilitation techniques based 
on neuroplasticity may be potentially significant to embrace approaches grounded on clinical and basic sciences highlighted over the past years [11,12]. At present, some techniques used in occupational and physical therapy may improve hemiparesis of upper limbs in stroke patients $[13,14]$. Even though physical therapy has been underlined to be applied immediately after brain damage [15], convincingly results pointing out to stroke rehabilitation as an efficient technique have been seen even some months or years after the first event (i.e., "chronic" stage) $[16,17]$. Nevertheless, the advantages of therapeutic approaches aiming to promote functional recovery of motor functions of stroke patients have been observed [18, 19]. Newer rehabilitation techniques reinforce the importance of the specific practice of motor tasks (i.e., repetitive task specific practice) with the affected limb, requiring many sessions of high-duration therapy [20]. Keeping this in mind, in an attempt to reduce motor deficits and to speed up the process of functional recovery, several researchers suggested mental practice (MP) like an additional source (i.e., adjunct technique) to promote motor restoration after stroke [21-23]. $\mathrm{MP}$ is based on motor imagery, which motor acts are cognitively rehearsed. In addition, it has been demonstrated potential results in functional recovery of the affected arm of stroke patients, leading to the motor relearning process [24-27]. By definition, motor imagery consists of an active operation whose the motor action is internally reproduced into working memory without real movements [28-30]. MP promotes improvements in motor learning and performance when included in rehabilitative strategies [31-33], leading to an activation of the same neural and muscular substrates when a mental simulation of motor acts occurs during performance of the same task $[34,35]$. Neuroimaging studies have demonstrated similar activity when compared real with imagined movements, supplying evidence that those similarities are based on the same process $[29,36]$. Within this context, the combination of MP with physical and occupational therapy appears to be a natural complement based on neurorehabilitation concepts. Thus, our study seeks to investigate if MP for stroke rehabilitation of upper limbs is an effective adjunct therapy.

\section{METHODS}

\section{Eligibility Criteria}

We will adopt the PICOS (population, intervention, group being compared, results and research design) recommendation to determine the eligibility.

1- Population: men and/or women, physically active or not, with diagnosis of stroke, aged 18 to 80 ;

2- Intervention: patients should be submitted to a condition of MP or not, plus physical practice involving the same exercises;

3- Compared to control groups: a control group (i.e., placebo) that did not receive MP intervention was necessary for comparison;

4- Outcomes: instruments to assess the effects of MP sensorimotor deficits on upper limbs of post stroke patients;

5- Study design: randomized controlled trials and nonrandomized studies were used to evaluate the effects of MP on sensorimotor deficits of upper limbs of post stroke patients

\section{Sources}


For the collection of studies the electronic databases MEDLINE/PubMed, ISI Web of Knowledge and SciELO will be accessed. Experts on the subject of the present study were also contacted to send articles. To find additional articles, all tables were examined for evidence of previous systematic reviews and found references to randomized controlled trials as necessary. In addition, we analyzed the references of all selected articles. The search was terminated on 20 February 2015.

\section{Search}

We use an advanced search on the ISI Web of Science, MEDLINE/PubMed and Scielo databases with the keywords: motor imagery, movement imagery, mental practice, sensorimotor deficits, upper limbs and stroke. The combination of terms used was: motor imagery AND sensorimotor deficits OR upper limbs with stroke, mental practice AND sensorimotor deficits OR upper limbs with stroke, movement imagery AND sensorimotor deficits OR upper limbs with stroke.

\section{Selection of Studies}

The selection of studies was performed by two independent researchers that in case of disagreement sought a consensus on the selection. The evaluation consisted of a selection of studies by analysis of the title, followed by analysis of the summary and then the analysis of the full text. With the disagreement between the two researchers, a third one was requested to finish the process. Relevant articles were obtained and assessed for inclusion and exclusion criteria described above.

\section{Data Collection}

The following data were extracted from the articles: sample size, configuration of mental practice, setting the physical practice (intensity, number of sets and repetitions, duration of contractions, rest interval between sets, weekly and total duration), measures of sensorimotor deficits used in the main studies and significant results. In addition, other information about the methods and outcomes were collected. These procedures were performed by two independent investigators, who reached a consensus in case of disagreement.

\section{Exclusion}

Criteria We excluded articles that had no intervention of mental practice, those who used other interventions associated with mental practice that could create a risk of bias in the study. In addition, studies that did not have a control group, samples aged out of 18-80, individuals with mental illness or neurological disease, except by stroke, that could create a risk of bias in the study were removed. The studies that did not detail the statistical procedure applied, or not presented the results of measurements before and after interventions.

\section{Statistical Analysis}

We estimated the pooled effect size by standardized mean differences (SMD), as the selected studies used different scales of measurement. According to Higgins and Green [37], 12 statistics under $40 \%$ suggest that heterogeneity among studies might not be important. Values over $75 \%$ indicate considerable heterogeneity, which was the case for the SMD. For this reason we used random effects models that take into account the variance between studies. Forest plots were used to present these findings. They were built in a way that the point estimates (SMD) and 95\% $\mathrm{Cl}$ of individual studies were graphically displayed in each line and the pooled measure was 
shown at the bottom. Larger Horizontal lines indicate less precise studies (small effect). The columns to the right present the numerical findings and the relative weights received by each study in the process of combining them.

Estimates with $\mathrm{p}$ values $\leq 0.05$ were considered statistically significant whilst values between 0.06 and 0.10 were suggestive of association. All analyses were performed using Stata 10.0.

\section{RESULTS}

Based on the defined criteria, a total of 934 articles were found in the search conducted in the literature (558 in Pubmed, 376 in ISI Web of Science, 0 in Scielo). After duplicates removal $(n=59), 875$ articles remained to be analysed by title and abstracts. After the screening, 865 articles were excluded, which were not related to the proposed theme. Therefore, 10 articles were analysed by eligibility criteria and by exclusion criteria. Thus, 7 studies were selected which were properly met the criteria for this review (see Fig. 1 and Table 1).

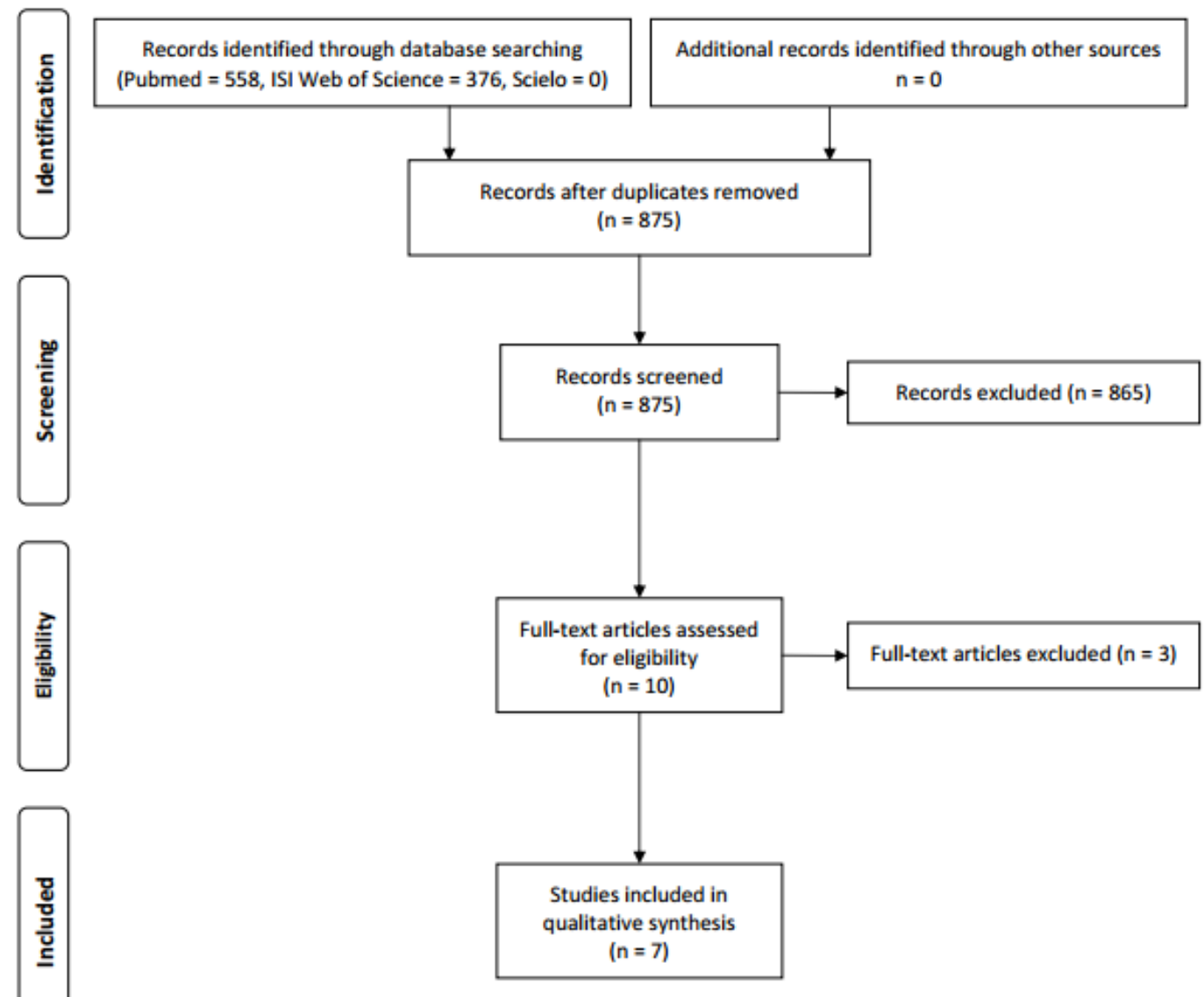

Fig. (1). Flow chart for the articles included in the meta-analysis. 
Table 1. Studies investigations the effect of MP as an effective adjunct therapeutic strategy for upper limb motor restoration after stroke.

\begin{tabular}{|c|c|c|c|c|c|c|}
\hline References & Sample & Type of Study & Supervised & Intervention & Instruments & Main Results \\
\hline Page et al. [38] & $\begin{array}{c}\mathrm{n}=8 \\
\text { (MP Group) } \\
\mathrm{n}=8 \\
\text { (Control Group) } \\
\text { Chronic Phase }\end{array}$ & $\begin{array}{l}\text { Randomized } \\
\text { Clinical Trial }\end{array}$ & $\begin{array}{c}\text { Yes } \\
\text { Occupational } \\
\text { therapist }\end{array}$ & $\begin{array}{c}\text { MP Group } \\
\text { Physical Practice - exercises for more affected arm } \\
\text { Duration: } 1 \text { hour } \\
\text { Frequency: } 3 \text { times per week } \\
\text { Total: } 4 \text { weeks } \\
\text { MP- exercises for more affected arm } \\
\text { Duration: } 10 \text { min } \\
\text { Frequency: } 3 \text { times per week } \\
\text { Tonal: } 4 \text { weeks } \\
\text { Control Group } \\
\text { Physical Practice - exercises for more affected arm } \\
\text { Duration: } 1 \text { hour } \\
\text { Frequency: } 3 \text { times per week } \\
\text { Tonal: } 4 \text { weeks } \\
\text { Relaxation } \\
\text { Duration: } 10 \text { min } \\
\text { Frequency: } 3 \text { times weeks } \\
\text { Tonal: } 4 \text { weeks }\end{array}$ & FMS & $\begin{array}{l}\text { Reduction in } \\
\text { sensorimotor deficits, } \\
\text { verified by FMS in MP } \\
\text { group significantly more } \\
\text { improved function than } \\
\text { those receiving Control } \\
\text { group. }\end{array}$ \\
\hline Page et al. [39] & $\begin{array}{c}\mathrm{n}=6 \\
\text { (MP Group) } \\
\mathrm{n}=5 \\
\text { (Control Group) } \\
\text { Chronic Phase }\end{array}$ & $\begin{array}{l}\text { Randomized } \\
\text { Clinical Trial }\end{array}$ & $\begin{array}{c}\text { Yes } \\
\text { Oecupational } \\
\text { therapist }\end{array}$ & \begin{tabular}{|c|} 
MP Group \\
Physical Practice + MP - exercises for more \\
affected arm \\
Duration: 30 min \\
Frequency: 2 times per week \\
Tonal. 6 weeks \\
Control Group \\
Physical Practice - exercises for more affected arm \\
+ relaxation \\
Duration: 30 min \\
Frequency: 2 times per week \\
Tonal: 6 weeks
\end{tabular} & ARAT & $\begin{array}{l}\text { Improwement of } \\
\text { functions in the more } \\
\text { affected arm, verified by } \\
\text { ARAT. }\end{array}$ \\
\hline Page et al. [40] & $\begin{array}{c}\mathrm{n}=16 \\
\text { (MP Group) } \\
\mathrm{n}=16 \\
\text { (Control Group) } \\
\text { Chronic Phase }\end{array}$ & $\begin{array}{l}\text { Randomized } \\
\text { Clinical Trial }\end{array}$ & $\begin{array}{c}\text { Yes } \\
\text { Occupational } \\
\text { therapist }\end{array}$ & $\begin{array}{c}\text { MP Group } \\
\text { Physical Practice + MP - exercises for more } \\
\text { affected arm } \\
\text { Duration: } 30 \text { min } \\
\text { Frequency: } 2 \text { times per week } \\
\text { Total: } 6 \text { weeks } \\
\text { Control Group } \\
\text { Physical Practice - exercises for more affected arm } \\
\text { + relaxation } \\
\text { Duration: } 30 \text { min } \\
\text { Frequency: } 2 \text { times per week } \\
\text { Total: } 6 \text { weeks }\end{array}$ & $\begin{array}{l}\text { ARAT } \\
\text { FMS }\end{array}$ & $\begin{array}{l}\text { Reduction in } \\
\text { sensorimotor deficits and } \\
\text { improvement of } \\
\text { functions in the more } \\
\text { affected arm, verified by } \\
\text { ARAT and FMS } \\
\text { respectively and } \\
\text { development } \\
\text { of new skills. }\end{array}$ \\
\hline
\end{tabular}




\begin{tabular}{|c|c|c|c|c|c|c|}
\hline References & Sample & Type of Study & Supervised & Intervention & Instruments & Main Results \\
\hline Page et al. [41] & $\begin{array}{c}\mathrm{n}=5 \\
\text { (grupo MP) } \\
\mathrm{n}=5 \\
\text { (Control Group) } \\
\text { Chronic Phase }\end{array}$ & $\begin{array}{l}\text { Randomized } \\
\text { Clinical Trial }\end{array}$ & $\begin{array}{c}\text { Yes } \\
\text { Occupational } \\
\text { therapist } \\
\text { MP } \\
\text { intervention } \\
\text { was self- } \\
\text { administered } \\
\text { by an } \\
\text { audiotape. }\end{array}$ & $\begin{array}{c}\text { MP Group } \\
\text { mCIMT - for more affected arm } \\
\text { Duration: } 2 \text { hours } \\
\text { Frequency: } 3 \text { days per week } \\
\text { Total: } 10 \text { weeks } \\
\text { mCIMT - for less affected arm restraint } \\
\text { Duration: } 5 \text { hours } \\
\text { Frequency: } 5 \text { days per week } \\
\text { Total: } 10 \text { weeks } \\
\text { MP - emphasizing activities of daily living - ADLs } \\
\text { Duration: } 30 \text { min } \\
\text { Frequency: } 5 \text { days per week } \\
\text { Total: } 10 \text { weeks } \\
\text { Control Group } \\
\text { mCIMT - for more affected arm } \\
\text { Duration: } 2 \text { hours } \\
\text { Frequency: } 3 \text { days per week } \\
\text { Total: } 10 \text { weeks } \\
\text { mCIMT - for less affected arm restraint } \\
\text { Duration: } 5 \text { hours } \\
\text { Frequency: } 5 \text { days per week } \\
\text { Total: } 10 \text { weeks }\end{array}$ & $\begin{array}{l}\text { FMS } \\
\text { ARAT }\end{array}$ & $\begin{array}{l}\text { All patients exhibited } \\
\text { stable, affected arm } \\
\text { motor deficits, as } \\
\text { verified by FMS and } \\
\text { ARAT. Patients who } \\
\text { received mCIMT + MP } \\
\text { exhibited significantly } \\
\text { larger changes on both } \\
\text { motor measures as } \\
\text { compared to the patients } \\
\text { who received only } \\
\text { mCIMT, as verified by } \\
\text { ARAT and FMS, } \\
\text { sustained during } 3 \\
\text { morths after } \\
\text { intervention. }\end{array}$ \\
\hline $\begin{array}{l}\text { Riecio et al. } \\
\quad \text { [42] }\end{array}$ & $\begin{array}{c}\mathrm{n}=18 \\
\text { (MP Group) } \\
\mathrm{n}=18 \\
\text { (Control Group) } \\
\text { Prase not cited }\end{array}$ & $\begin{array}{l}\text { Randomized } \\
\text { Clinical Trial }\end{array}$ & $\begin{array}{l}\text { No cited } \\
\text { Assessmerts } \\
\text { were carried } \\
\text { out by a } \\
\text { physiatrist }\end{array}$ & 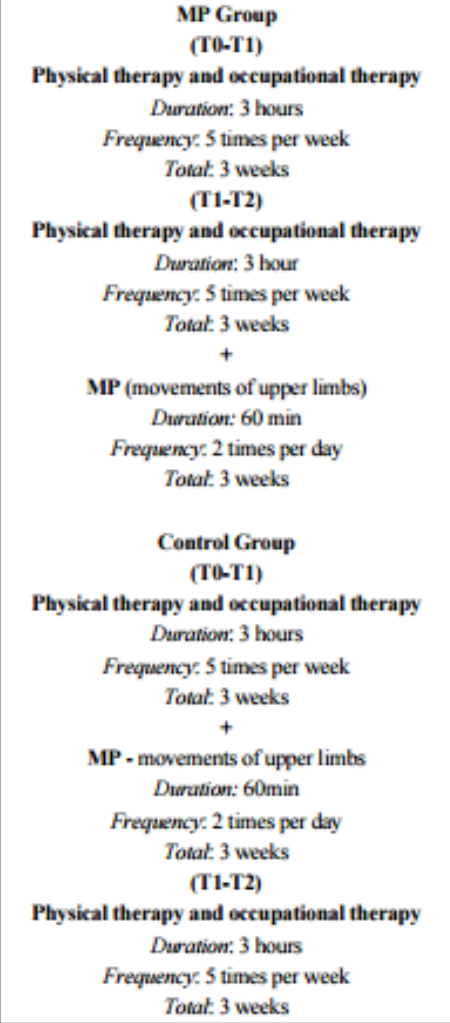 & $\begin{array}{l}\text { AFT } \\
\text { MI }\end{array}$ & $\begin{array}{l}\text { Results showed } \\
\text { improvements in } \\
\text { stsength, motor control } \\
\text { and execution speed, } \\
\text { examined by ARAT and } \\
\text { MI tes, markedly } \\
\text { between T1 and T2 in } \\
\text { group A and between T0 } \\
\text { and T1 in group B. MP } \\
\text { was used in these } \\
\text { moments. }\end{array}$ \\
\hline
\end{tabular}




\begin{tabular}{|c|c|c|c|c|c|c|}
\hline References & Sample & Type of Study & Supervised & Intervention & Instruments & Main Results \\
\hline $\begin{array}{l}\text { Bovend'Eerdt } \\
\text { et al. [43] }\end{array}$ & $\begin{array}{c}\mathrm{n}=15 \\
\text { (MP Group) } \\
\mathrm{n}=15 \\
\text { (Control Group) } \\
\\
\text { Chronic Phase }\end{array}$ & $\begin{array}{l}\text { Randomized } \\
\text { Clinical Trial. }\end{array}$ & $\begin{array}{c}\text { Yes } \\
\text { Physiotherapy } \\
\text { and } \\
\text { occupational } \\
\text { therapy. }\end{array}$ & $\begin{array}{l}\text { MP Group } \\
\text { Physical therapy and occupational therapy + } \\
\text { MP - imagery videos } \\
\text { Duration: } 3 \text { hours } \\
\text { Frequency: } 3 \text { times per week during first } 3 \text { weeks } \\
\text { and } 2 \text { times per week during the remaining } 3 \text { weeks } \\
\text { Total: } 6 \text { weeks } \\
\text { Control Group } \\
\text { Physical therapy and occupational therapy + } \\
\text { Videos with rehabilitation information } \\
\text { Duration: } 3 \text { hours } \\
\text { Frequemcy: } 3 \text { times per week during first } 3 \text { weeks } \\
\text { and } 2 \text { times per week during the remaining } 3 \text { weeks } \\
\text { Totat. } 6 \text { weeks }\end{array}$ & ARAT & $\begin{array}{l}\text { Both groups showed } \\
\text { improvement as verified } \\
\text { by ARAT with no } \\
\text { difference in time } \\
\text { between groups. }\end{array}$ \\
\hline $\begin{array}{c}\text { Hemmen ef al. } \\
\text { [44] }\end{array}$ & $\begin{array}{c}\mathrm{n}=14 \\
\text { (MP Group) } \\
\mathrm{n}=13 \\
\text { (Control Group) } \\
\text { Subacute Phase }\end{array}$ & $\begin{array}{l}\text { Randomized } \\
\text { Clinical Trial }\end{array}$ & $\begin{array}{l}\text { Not eited } \\
\text { Tests were } \\
\text { administered } \\
\text { by one of three } \\
\text { experienced } \\
\text { occupational } \\
\text { therapists. }\end{array}$ & $\begin{array}{l}\text { MP Group } \\
\text { Eleetrestimulation - stimulation of the wrist } \\
\text { extensor muscles } \\
\text { Duration: } 30 \text { min } \\
\text { Frequency: } 3 \text { days per week } \\
\text { Total: } 12 \text { weeks } \\
\text { MP - wrist extension movements } \\
\text { Duration: } 30 \text { min } \\
\text { Frequency: } 3 \text { days per week } \\
\text { Total: } 12 \text { weeks } \\
\text { Control Group } \\
\text { Electrostimulation - stimulation of the wrist } \\
\text { extensor muscles } \\
\text { Duration: } 30 \text { min } \\
\text { Frequency: } 3 \text { days per week } \\
\text { Total: } 12 \text { weeks }\end{array}$ & $\begin{array}{c}\text { Brunnstrom } \\
\text { FMS } \\
\text { ARAT }\end{array}$ & $\begin{array}{l}\text { Both groups improved in } \\
\text { functionality of the } \\
\text { affected arm by } 8.7 \text { and } \\
19.4 \text { points verified by } \\
\text { Brunnstrom, FMS and } \\
\text { ARAT, respectively, } \\
\text { compared to pre- } \\
\text { treatment. There were no } \\
\text { significant effects } \\
\text { between groups. }\end{array}$ \\
\hline
\end{tabular}

Fig. (2) presents the standardized average differences in two groups (mental practice and control). The heterogeneity in studies was high $(12=78.8 \%)$. As there was no statistically significant difference between the two groups (MP vs control), showed a -0.6 ( $95 \% \mathrm{Cl}:-1.27$ to 0.04), for upper limb motor restoration after stroke. 


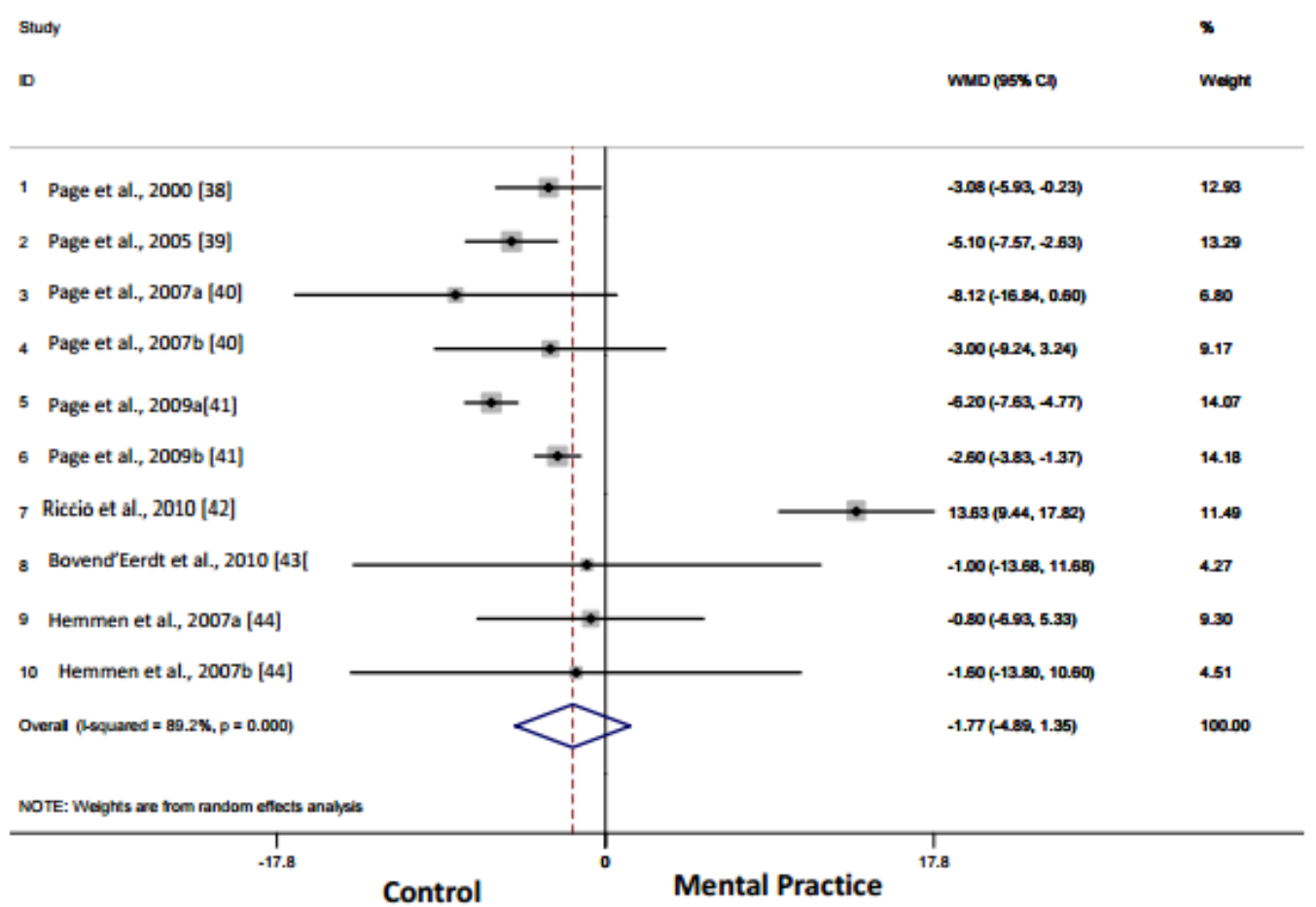

Fig. (2). Meta-analysis of studies that assessed the effects of MP as an effective adjunct therapeutic strategy for upper limb motor restoration after stroke.

\section{DISCUSSION}

Our objective was to examine if the combination of MP with physical and occupational therapy is an effective adjunct therapy for stroke rehabilitation of upper limbs. It is well known that MP can improve motor gestures and sports skills [27-29]. There is also evidence that brain regions involved in movement performance are also active during an imagined movement [31-33]. Despite we found studies showing positive findings in favor of MP [38-42], our metaanalysis demonstrated opposite results. Understanding that the MP alone was not able to promote significant effects on muscle strength [45], in our current meta-analysis, the results showed that even as adjunctive intervention method with physical therapy or occupational therapy, MP was not effective in rehabilitation of upper limbs after stroke. The understanding of neural mechanisms of MP is not yet fully understood, and it is reasonable to suppose that there are similarities in neural mechanisms between motor execution and MP. A possible hypothesis about the mechanisms of MP is that it could lead to changes in motor unit recruitment, synchronization and/or firing frequency [46]. Within this context, Ranganathan et al. [47] suggested that MP allows the brain to generate strong signals transmitted to the muscles. There is a high correlation between regional cerebral blood flow seen by positron emission tomography and voluntary force levels in several cortical motor areas [48]. Likewise, there was a positive correlation between the signal strength and the levels of activity on functional magnetic resonance imaging [49]. We can try to explain the supposed mechanism of improvement, linking MP to dopamine release by corticostriatal pathways associated with primary motor area. These connections are associated with learning a new pattern of movement and the formation of a new motor memory [50]. Assuming that regional cortical activity in the primary motor area is increased with the MP, as proposed in literature [38, 51], perhaps this may be reflected in an increase of the specific input of this neurotransmitter. Previous studies 
of patients with Parkinson's disease discuss the important role of dopaminergic inputs in the imaginary motor translation for real motor task performance [48]. Despite the neurophysiological events described, these mechanisms are still inconsistent in the perspective of MP and its influence on rehabilitation after stroke. Given our results, the relevance of such a mechanism is debatable. Methodological differences or significant limitations among the studies may have contributed to some way in our results. An important question is to know when to intervene with MP becomes effective in motor rehabilitation of upper limbs in post-stroke patients. Our results showed that, out of the seven studies selected for the meta-analysis, only the study by Riccio et al. [42] showed improvements in rehabilitation when MP was added to physical therapy. Riccio et al. [42] using an appropriate methodological design found significant results from the instruments (i.e., Arm Functional Test, Motricity Index, Functional Ability Scale), providing information about the quality of performance, ability and driving force. The studies that do not showed favorable effects to inclusion of MP had important limitations related to sample size [38, 39, 41]. In addition, the study Page et al. [38] used in addition to the MP with the affected limb, physical stimulation to the non-affected limb, and this may have contributed to possible differences due to possible contralateral strength gains [52]. It seems that the compromise of the integrity of anatomical structures is the key factor to no improvements in motor functions of poststroke patients [34]. There was also great variation on the instruments used to assessment, and therefore make difficult future comparisons. With the exception of Page et al. [38-41] that conducted most of the included studies, and then the instruments are comparable, Bovend'Eerdt et al. [43] used instruments to assess attention, learning and memory, as well as the motor functions to investigate the effects of MP (Short Orientation Memory Concentration Test-and Motricity index). Even with experiments demonstrating that MP combined with physical activity (i.e., physical and occupational therapy) is effective on reduction of sensorimotor deficits in stroke patients [38-41], our meta-analysis demonstrated the opposite findings. Due to the diversity of methodologies used in the studies, such as frequency, duration, volume and limb, we found a high discrepancy in the results, making it difficult to establish useful recommendations for use of MP. Reduction in sensorimotor deficits may be due to familiarization with the exercises, since favorable results were found in control groups $[43,44]$. Thus, we cannot claim that MP is an effective alternative to provide sensorimotor gains, but its application can be an alternative in cases where the impossibility of performing motor rehabilitation for maintaining motor functions during short periods of detraining or as an adjunct treatment to traditional stroke rehabilitation.

\section{CONCLUSION}

The present meta-analysis concluded that MP is not effective as adjunct therapeutic strategy for upper limb motor restoration after stroke. Thus, it is recommended that further studies must be conducted to determine specific parameters such as number and weekly frequency, duration (minutes per session), type (visual or kinesthetic) and the appropriate moment to apply mental practice (phases recovery of pathology), in order to create specific protocols for each treatment phase. In addition, it is also necessary further studies with this same design using neuroimaging techniques in order to obtain more information about the patterns of brain activation and reorganization.

\section{LIST OF ABBREVIATIONS}

ARAT $=$ Action Research Arm Test

FMS = Fulg Meyer Scale 
$\mathrm{mCIMT}=$ Modified Constraint Induced Movement Therapy

$\mathrm{MP}=$ Mental Practice

SMD = Standardized Mean Differences

\section{REFERENCES}

[1] Kleindorfer D, Broderick J, Khoury J, et al. The unchanging incidence and case-fatality of stroke in the 1990s: a populationbased study. Stroke 2006; 37: 2473-8.

[2] Rosamond W, Flegal K, Furie K, et al. Heart disease and stroke statistics-2008 update: a report from the American Heart Association Statistics Committee and Stroke Statistics Subcommittee. Circulation 2008; 117: 125-46.

[3] Cicerone KD, Dahlberg C, Malec JF, et al. Evidence-based cognitive rehabilitation: updated review of the literature from 1998 through 2002. Arch Phys Med Rehabil 2005; 86: 1681-92.

[4] Gray V, Rice CL, Garland SJ. Factors that influence muscle weakness following stroke and their clinical implications: a critical review. Physiother Can 2012; 64(4): 415-26.

[5] Buma F, Kwakkel G, Ramsey N. Understanding upper limb recovery after stroke. Restor Neurol Neurosci 2013; 31(6): 707-22.

[6] de Pedro-Cuesta J, Widen-Holmquist L, Bach-y-Rita P. Evaluation of stroke rehabilitation by randomized controlled studies: a review. Acta Neurol Scand 1992; 86: 433-9.

[7] Duncan PW. Synthesis of intervention trails to improve motor recovery following stroke. Top Stroke Rehabil 1997; 3: 1-20.

[8] Kwakkel G, Kollen BJ, Wagenaar RC. Therapy impact on functional recovery in stroke rehabilitation: a critical review of the literature. Physiotherapy 1999; 13: 457-70.

[9] Duncan PW GL, Matchar D, Divine GW, Feussner J. Measurement of motor recovery after stroke. Outcome assessment and sample size requirements. Stroke 1992; 23: 1084-9.

[10] Liepert J, Bauder H, Miltner WHR, Taub E, Weiller C. Treatment induced cortical reorganization after stroke in humans. Stroke 2000; 31: 1210-6.

[11] Ward NS Cohen LG. Mechanisms underlying recovery of motor function after stroke. Arch Neurol 2004; 61: 1844-8.

[12] Calautti C, Baron JC. Functional neuroimaging studies of motor recovery after stroke in adults: A review. Stroke 2003; 34: 1553-66.

[13] Stevenson T, Thalman L, Christie H, Poluha W. ConstraintInduced Movement Therapy Compared to Dose-Matched Interventions for Upper-Limb Dysfunction in Adult Survivors of Stroke: A Systematic Review with Meta-analysis. Physiother Can 2012; 64(4): 397-413.

[14] Doyle SD, Bennett S, Dudgeon B. Upper limb post-stroke sensory impairments: the survivor's experience. Disabil Rehabil 2014; 36(12): 993-1000. 
[15] Kunkel A, Kopp B, Müller GV, illringer K, Villringer A, Taub E, Flor H. Constraint-induced movement therapy for motor recovery in chronic stroke patients. Arch Phys Med Rehabil 1999; 80: 624-8.

[16] Plummer P, Eskes G, Wallace S, et al. Cognitive-Motor Interference during Functional Mobility after Stroke: State of the Science and Implications for Future Research. Arch Phys Med Rehabil 2013; 94(12): 2565-74.

[17] Hummelsheim H. Rationales for improving motor function. Curr Opin Neurol 1999; 12: 697701.

[18] Bishop L, Stein J. Three upper limb robotic devices for stroke rehabilitation: A review and clinical perspective. NeuroRehabilitation 2013; 33(1): 3-11.

[19] Wolf SL, Winstein CJ, Miller JP, et al. Effect of constraint-induced movement therapy on upper extremity function 3 to 9 months after stroke: the EXCITE randomized clinical trial. JAMA 2006; 296: 2095-104.

[20] Volpe BT, Ferraro M, Lynch D, et al. Robotics and other devices in the treatment of patients recovering from stroke. Curr Neurol Neurosci Rep 2005; 5: 465-70.

[21] Van Leeuwen R, Inglis JT. Mental practice and imagery: a potential role in stroke rehabilitation. Phys Ther Rev 1998; 3: 47- 52.

[22] Warner L, McNeill ME. Mental imagery and its potential for physical therapy. Phys Ther 1988; 68: 516-21.

[23] Malouin F, Richards CL, Durand A, Doyon J. Clinical assessment of motor imagery after stroke. Neurorehabil Neural Repair 2008; 22: 330-40.

[24] Dijkerman HC, Letswaart M, Johnston M, MacWalter RS. Does motor imagery training improve hand function in chronic stroke patients? A pilot study. Clin Rehabil 2004; 18: 538-49.

[25] Page SJ, Levine P, Leonard AC. Effects of mental practice on affected limb use and function in chronic stroke. Arch Phys Med Rehabil 2005; 86: 399-402.

[26] Hewitt TE, Ford K, Levine P, Page SJ. Reaching kinematics to measure motor changes after mental practice in stroke. Top Stroke Rehabil 2007; 14: 23-9.

[27] Decety J, Grèzes J. Neural mechanisms subserving the perception of human actions. Trends Cogn Sci 1999; 3: 172-8.

[28] Jeannerod M. Neural simulation of action: a unifying mechanism for motor cognition. Neurolmage 2001; 14: 103-9.

[29] Lotze M, Cohen LG. Volition and imagery in neurorehabilitation. Cogn Behav Neurol 2006; 19: $135-40$.

[30] Munzert J, Lorey B, Zentgraf K. Cognitive motor processes: the role of motor imagery in the study of motor representations. Brain Res Rev 2009; 60(2): 306-26.

[31] Jeannerod $M$, Anquetil T. Putting oneself in the perspective of the other: a framework for self-other differentiation. Soc Neurosci 2008; 3(3-4): 356-67.

[32] Jeannerod M. Being oneself. J Physiol Paris 2007; 101(4-6): 161-8. 
[33] Decety J. Do imagined and executed actions share the same neural substrate? Cog Brain Res 1996; 3: 87-93.

[34] Decety J. The neurophysiological basis of motor imagery. Behav Brain Res 1996; 77: 45-52.

[35] Michelon P, Vettel JM, Zacks JM. Lateral somatotopic organization during imagined and prepared movements. J Neurophysiol 2006; 95: 811-22.

[36] Jackson PL, Lafleur MF, Malouin F, Richards C, Doyon J. Potential role of mental practice using motor imagery in neurologic rehabilitation. Arch Phys Med Rehabil 2001; 82: 1133-41.

[37] Higgins JP, Green S: Cochrane Handbook for Systematic Reviews of Interventions. Chichester, Wiley, 2008, vol 8, p. 649.

[38] Page SJ. Imagery improves motor function in chronic stroke patients with hemiplegia: a pilot study. Occ Ther J Res 2000; 20: 200-15.

[39] Page SJ, Levine $P$, Leonard AC. Effects of mental practice on affected limb use and function in chronic stroke. Arch Phys Med Rehabil 2005; 86: 399-402.

[40] Page SJ, Levine P, Leonard A. Mental practice in chronic stroke: results of a randomized, placebo-controlled trial. Stroke 2007; 38: 1293-7.

[41] Page SJ, Levine P, Khoury JC. Modified constraint-induced therapy combined with mental practice: thinking through better motor outcomes. Stroke 2009; 40(2): 551-4.

[42] Riccio I, Iolascon G, Barillari MR, Gimigliano R, Gimigliano F. Mental practice is effective in upper limb recovery after stroke: a randomized single-blind cross-over study. Eur J Phys Rehabil Med 2010; 46(1): 19-25.

[43] Bovend'Eerdt TJ, Dawes H, Sackley C, Izadi H, Wade DT. An integrated motor imagery program to improve functional task performance in neurorehabilitation: a single-blind randomized controlled trial. Arch Phys Med Rehabil 2010; 91(6): 939-46.

[44] Hemmen B, Seelen HA. Effects of movement imagery and electromyography-triggered feedback on arm hand function in stroke patients in the subacute phase. Clin Rehabil 2007; 21(7): 587-94.

[45] Manochio JP, Lattari E, Portugal EMM, et al. From Mind to Body: Is Mental practice effective on strength gains? A metanalysis. CNS Neurol Disord Drug Targets 2015; in press.

[46] Brody EB, Hatfield BD, Spalding TW, Frazer MB, Caherty FJ. The effect of a psyching strategy on neuromuscular activation and force production in strength-trained men. Res Q Exerc Sport 2000; 71(2): 162-70.

[47] Ranganathan VK, Siemionow V, Liu JZ, Sahgal V, Yue GH. From mental power to muscle power--gaining strength by using the mind. Neuropsychology 2004; 42(7): 944-56.

[48] Dettmers C, Fink GR, Lemon RN, Stephan KM, Passingham RE, Silbersweig, D. Relation between cerebral activity and force in the motor areas of the human brain. J Neurophysiol 1995; 74(2): 802- 15 .

[49] Dai TH, Liu JZ, Siemionow V, Ng TC, Yue GH. Simultaneous measurements of human functional MRI, muscle force and EMG. Soc Neurosci Abstr 1999; 25: 1915. 
[50] Kawashima S, Ueki Y, Kato T, et al. Changes in striatal dopamine release associated with human motor-skill acquisition. PLoS One 2012; 7(2): e31728.

[51] Kuhtz-Buschbeck JP, Mahnkopf C, Holzknecht C, Siebner H, Ulmer S, Jansen O. Effectorindependent representations of simple and complex imagined finger movements: a combined fMRI and TMS study. Eur J Neurosci 2003; 18(12): 3375-87.

[52] Farthing JP, Borowsky R, Chilibeck PD, Binsted G, Sarty GE. Neuro-physiological adaptations associated with cross-education of strength. Brain Topogr 2007; 20(2): 77-88. 